\title{
Debret and Public Archeology: The Tikuna Mask and the Fire of the National Museumain
}

\author{
Mariane Pimentel Tutui* \\ Master in History, University Estadual de Maringá, Brazil
}

Submission: April 16, 2019; Published: May 09, 2019

*Corresponding author: Mariane Pimentel Tutui, Master in History, University Estadual de Maringá, Rua Narlir Miguel, 897 - Centro. Postal Code: 18230-000. São Miguel Arcanjo, São Paulo, Brazil

\begin{abstract}
The object of study of archeology is the materiality left by previous societies. For this bias, Public Archeology seeks to share and disseminate archaeological knowledge with communities involved in research. This article aims to explain the Tikuna masks, especially the monkey head, observed and designed by the French artist Jean-Baptiste Debret during the French Artistic Mission in Brazil and published in his work Voyage Pittoresque et Historique au Brésil (1834) -1839). The mask was one of the highlights of the eighteenth-century collections of the National Museum in Rio de Janeiro, which suffered a fire in late 2018.
\end{abstract}

Keywords: Debret; Tikuna; National museum; Brazil; XIX century; Public archeology

\section{Perspective}

This article aims to guide its discussions in the defense of historical, artistic and cultural patrimony and, above all, to provide a basis for a better understanding of the social issues that surround the theme of "Public Archeology" through the works of the French artist Jean-Baptiste Debret (referring to the masks Tikuna). It is hoped to contribute to the dissemination of questions and to the reproduction of critical thoughts about this theme. Before we go into the issues related to the watercolors of Debret and the fire in the National Museum, it is important to discuss public archeology. The expression "Public Archeology" [1] refers to the interaction with people, providing dialogues and discussions about symbologies and representations constituted through material culture. For this, the focus of Public Archeology is to seek greater interaction and sharing with the public about archaeological knowledge, promoting awareness in society regarding the preservation of patrimony. That is, the work in the field of Public Archeology is concerned with political and social issues, which contribute to the interest of society in scientific, economic and educational aspects. Therefore, state intervention within Public Archeology concerns aspects of legislation in terms of environmental and cultural protection. Public Archeology comes every year, reaching new possibilities and perspectives. Developing as an interdisciplinary field of study, one of its main objectives is to enable interaction with society to recover and preserve its own history (FUNARI; ROBRAHNGONZÁLVEZ, 2006, p.3).

So that the knowledge coming from academic research is not limited only to the academic environment and encompasses all publics, Public Archeology has as one of its objectives, the publicity of archaeological science. With the bonds of identity strengthened, memory helps the history lived by individuals, whose memories and ideas are generated within the communities. Therefore, Public Archeology has the social function of transmitting the public value of the archaeological heritage, seeking intense dialogues with the communities involved in projects focused on this theme. Having said that, we can enter our research object in the case of the debretian works. Jean-Baptiste Debret was born in France in 1768, nephewgrandson of François Boucher (1703-1770), a renowned Rococo master, Debret also had as mentor and teacher the master of the Neoclassical, Jacques-Louis David (1748- 1825). The French artist began his artistic studies at the Louis-Legrand High School in Paris and later at the Academy of Fine Arts. Still very young participates next to David, of the execution of the screen The oath of the Horácios [2] (work that illustrates the artistic ideals of neoclassicism). Debret also acted as painter of Napoleon Bonaparte, extolling the military campaigns, amalgamating art and politics and highlighting the battles that exalted the emperor. According to the philosopher and critic Jacques Leenhardt, Debret "left France from the French Revolution of the empire at the time Napoleon went into exile and his master Jacques-Louis David had to do the same with the arrival of the Restoration (1815) [3]".

With the opening of the ports fomented by D. João VI in 1808, the expeditions amplify. In the meantime, Debret integrates what we call today "Artistic French Mission" [4] and brings in 
the tropics in the year 1816, along with other artists of solid academic background [5]. Debret was the most persistent "Mission" artist in Brazil, in fifteen years produced the most extensive documentary on historical uses, customs, sights and events in the tropics. The iconographic legacy of Debret arouses a contemporary interest, since it will incite new reflections on Brazil and not only as the Brazilians were seen by the looks of foreigners. In this context, Debret acts as painter, draftsman, engraver, decorator, teacher and set designer; hired for a period of six years as an official court artist, the artist improvises his house in the neighborhood of Catumbi, located in the capital, Rio de Janeiro. With his solid artistic baggage brought from Europe, Debret strives to make an art that maintains a bond with the reality of the country and discovers through the watercolor technique an agility in its tracing, achieving in this way a critical interpretation in his paintings.

In this period of experience in the tropics, Debret made more than a thousand images [6], among them the flag, imperial coats of arms, allegories, coins, medals, portraits of the royal family, some works of architecture, taxonomic paintings referring to native flora and fauna. The different human types also caught the attention of the artist among them: tropeiros, gypsies, paulistas, miners; also represented the Indians and their tribes, as for example, the Camacãs, the Bugres, the Botocudos, the Guaianases, the Guaicurus, the Guaranis, the Tikuna among others. There are also some engravings relating to huts and huts, masks used by some Indians, Indian hairstyles, inscriptions engraved on cliffs, scepters and vestments of tribal chiefs, ceramics, wooden and clay utensils, and some weapons such as bow and arrow. The artist also describes the different vegetables used in food, necklaces and tattoos made by Indians (yams, cipó, aipim, urucu, genipapo, among others).

In 1829 Debret organizes the first public art exhibition in Brazil, paying from his own pocket the edition of the catalog with 115 works. The artist participates in the hall with ten works of his own, including the ceiling design of the Hall of the Academy.

The following year occurs the second hall and Debret is elected corresponding member of the Academy of Fine Arts of the Institute of France. 1831 is the year of his departure, the painter leaves Brazil and returns to Paris, where he receives decorations in the following years. He was unanimously elected as a titular member of the Institut Historique de Paris (1834), admitted as a corresponding member of the Historical and Geographical Institute of Brazil (IHGB) in 1840, decorated with the Legion of Honor in the official degree (1841) and made an honorary correspondent of the Academy of Fine Arts of the Institute of France (1842). The watercolors served as a basis for the engravings that the painter gathers and publishes in album format between 1834-1839, as soon as he returns to Europe. It is a written and illustrated work elaborated during the fifteen years lived in Brazil, with the title: Voyage Pittoresque et Historique au Brésil, constituted by three volumes, the first one being launched in 1834, the second in 1835 and the third and last volume in 1839. Debret intends to show readers a vision beyond the simple idea of an exotic and distant country, which was the interpretation given by Natural History and taxonomists.

Through minute details, the artist attempted to create a work both historical and cultural, since it represented simple people and different aspects of culture, religion and daily life in Brazil. In a total of 153 boards accompanied by texts, the artist elucidated his perceptions since he had landed in Guanabara Bay, Rio de Janeiro, in March 1816. In the first volume of Voyage Pittoresque (published in 1834), Debret depicts native vegetation and Indians, in the second volume (1835), slaves and urban work, and in the third and final volume (1839), festivals, traditions and cultural manifestations. It is important to emphasize that the recognition of all debretian work, as well as its prestige in Brazil, has been delayed due to the arrival of the photograph and also to the criticisms inserted in the Brazilian Historical and Geographical Institute (IHGB) [7]. It was not until 1940 (one hundred years after it was released) that Voyage Pittoresque et Historique au Brésil arrived in Brazil. In the first half of the twentieth century, discussions of nationalism, conducted with the modernist movement, brought to the forefront the interest of researchers and art collectors for the works of the past, which influenced the formation of large collections. It is in this context that we will explain about the Tikuna masks, especially the monkey head, observed and designed by the French artist and published in Voyage Pittoresque et Historique au Brésil.

According to Bandeira, Debret could not observe the Indians in their wild habitat and most of the details in their engravings and watercolors were copied from the work of other traveling artists [8] or objects preserved in the Museum of Rio de Janeiro. Thus, Debret had to use the observations of his predecessors, such as the naturalists Spix and Martius [9] and of the prince Maximiliano de Wied [10] . In the opinion of Bandeira and Lago, still the artist leaves us an interesting and valuable record regarding the Indians.

Among the indigenous artifacts that Debret represented in his watercolors, published in lithographs [11] colored in Voyage Pittoresque, we chose the masks, especially the Tikuna people.

The Tikuna are Amerindian peoples who traditionally live in a contiguous region comprising part of the territories of Brazil, Colombia and Peru. Their villages are on the banks of the Amazon River - Solimões and in sites located along tributary rivers. According to data from the Instituto Socioambiental (ISA) [12], are one of the largest indigenous groups in Brazil. The Tikuna speak an isolated language, their first recorded references in the Amazon region were by Cristóbal de Acuña (1597-1670), a Jesuit priest and clerk of the expedition of Pedro Teixeira, carried out from Belém to Quito in the years from 1637 to 1639. The contact of the Tikuna with the non-Indians occurred from the second half of the seventeenth century, intensifying in the late nineteenth century, when much of their land was occupied 
by rubber farmers and traders who lived from the extraction of rubber.

The Tikuna call themselves Magüta people, which means "people fished with stick." According to oral tradition [13], the origin of the Tikuna begins when Yo'i (mythological hero) fishes them in Igarapé Évare, located in the sources of Igarapé St. Jerome (tributary of the left bank of the river Solimões) and considered as a sacred place.

Among the sacred rituals performed, many authors consider the Ritual Da Moça Nova [14] as being one of the most important for the Tikuna due to its complexity and richness of details. The use of masks in initiation rituals in autochthonous populations signifies a kind of masculine cultural response to the powerful process of female transformation. In Tikuna society, the making of masks and their use, as well as musical instruments, are the exclusive domain of men. From the perspective of the anthropologist Jussara Gomes Gruber [15], the accounts of ethnological travelers have always been with their attentions turned to ritualistic masks; the effect of these masks on the eye of the observer is evident in the ethnographic collections of museums both in Brazil and abroad. The predominance of such artifacts in relation to the other items of material expressions attests to the propensity to focus on a product that, from the point of view of the collectors, was the most representative of the Tikuna culture.

Jean-Baptiste Debret observes and draws the Tikuna masks, later publishing them in the first volume of Voyage Pittoresque (1834). In her iconographic studies on the set of debretian works, the historian Valéria Lima establishes a double interpretative method for the analysis of the works of the artist. The first is to carry out a clash between the works and the text produced by Debret and the second asks for a look capable of investigating the iconography, seeking not only the verisimilitude of the works, but also the relations with the images produced by other travelers and the history of art in general. It is from this analysis that Lima demystifies the generic category that Debret is a "traveling artist". In the case of a very delicate bias, the historian is attentive to the terms. The main themes of his watercolors include the daily lives of slaves and urban habits, exactly what differentiates the French artist from other traveling artists. Moreover, contrary to travel accounts, Debret's work follows a pre-established program and not a chronological line as usual, ie for Lima, Debret does not make a travel account but a work of historiographic, due to the artist's classificatory intention in selecting, organizing and classifying groups. As an example the historian cites the separation of indigenous groups according to the familiarity with the Europeans, highlights the steps of approach and understanding by the slaves of the civilized habits, among other resources used by Debret. Another factor that would disqualify the artist from a traveler in the traditional sense would be the fact that Debret lived for fifteen years in Brazil, having a regular job as a painting teacher and as an official court painter.
On the different types of masks, the French artist describes on plate 39: It was only in truth that the industrious savage man, having exhausted all the resources of the tattoo, in order to become horrible, to manufacture animal-shaped masks of all kinds, the only means of physically reproducing the appearance of a more frightening monstrosity, and therefore worthy of all the admiration of the spectators on the feast days. It is what he did, and still more: not satisfied with this partial transformation, he was able to take advantage of the advantage of a long dress and a head to become a giant, in which his always active genius, rivaled that of the European couturiers (DEBRET, 2016, p.127). Still on the masks, Debret describes that "These gross imitations, really barbarous but executed with great care, present some degree of similarity with the object they must represent."

In the production of the masks, Gruber explains that the Tikuna used the weeds of some Amazonian trees and the ornamental motifs could be distributed over the entire dress. In the head, the decoration served to emphasize the features of the supernatural entity, but it was in the weaving that covered the body and observed a greater number of drawings. These drawings could imitate the skin of the entity represented or possess a more abstract stamp belonging only symbolically to a supernatural category. According to the author, in fact, the masks represent fear, the forces of nature, the legendary and ancestral animals, the sacred, the forces unknown, the phenomena of nature, the places, finally, the elements and values of culture Tikuna. Among the artist's descriptions, we find reports on jaguar, tapir, armadillo, winged human and plume, fish and monkey masks.

These ornaments of great importance are as light as solid, for they consist of a very thick cotton cloth, strongly gummed on both sides and painted next, which gives them the consistency of a hard and sonic body. The different colors employed are white, light yellow, red, brown and black (DEBRET, 2016, p. 127). Second, to decorate the masks, the Tikuna used a huge set of figures almost always represented in a naturalistic way and inspired by the regional fauna, with colorful colors obtained by a varied range of paints and extracted from natural resources, such as: saffron rhizome (for obtaining yellow); bure leaves (light blue); fruits of the pocova (black or dark blue); leaves of peach palm (green); Urucu (red); Brazilian Bark (light red and pink) [16].

In addition to the drawings of single masks, Debret also shows a complete scene performed in watercolor. From the perspective of the foreigner, it would be interesting to show the wild fun, so that we had an idea of the use of the masks in similar occasions. These masks belong to the collection of the Imperial Museum of Natural History [17] of Rio de Janeiro, where I designed them; attributed them to the Indians of Pará and, in fact, present the same character as those enjoyed by Spix and Martius among the savages Tacunas [18,19]. We observe in Figure 1 the monkey head mask of the Tikuna observed by Debret and that composes the representation of the Ritual of Moça Nova. One of 
the highlights of the nineteenth century collections of Brazilian indigenous ethnology from the National Museum in Rio de Janeiro, which suffered a fire at the end of 2018. The National Museum is located in the historic Palacio de São Cristóvão, in Quinta da Boa Vista, originated as a colonial institution, and its history was intertwined with that of the Brazilian nation. It is the scientific institution and the oldest museum in the country, having completed its bicentennial in 2018. On September 2, 2018, a fire of enormous proportions took over the museum destroying thousands of years of history of Brazil and the world [20], among the items consumed by the flames, were over 40,000 indigenous artifacts, including this Tikuna mask.

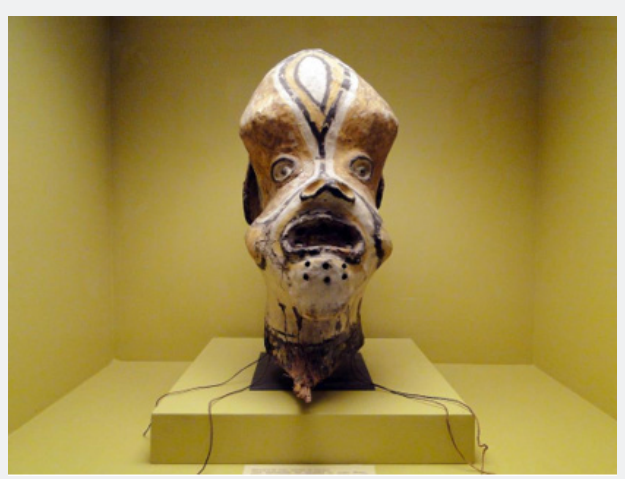

Dimensions: $51 \times 28 \times 32 \mathrm{~cm}$. 18th-19th century

Figure 1: Indian mask, representation of monkey's head reproduced in watercolor by Jean-Baptiste Debret [19] Place of collection / origin: Amazonas

The fire also destroyed a wealthy Amazon ethnographic collection of the nineteenth century that was in the basements of the traditional institution. The pieces that compose this collection were collected by the poet, lawyer, journalist, ethnographer and Brazilian theatologist Gonçalves Dias (1823-1964), who was part of the Scientific Commission of Exploration for the Universal Exhibition held in Rio de Janeiro in 1861. The collection was extensive and featured pieces from various Amazon peoples, such as arches, pieces, wooden benches, the production of ornaments with bird feathers, pots, baskets, pottery, ceramics, among other items. After the exhibition, this collection was transposed to the National Museum and has never been studied, remaining in the cellars [21]. Jean-Baptiste Debret observing the Tikuna mask, recreates the same object in watercolor. As we observed in Figure 2, the French artist represents the mask from various angles, indicating in the drawing up to the height of the object and maintaining the colors reliable if compared to the original piece.

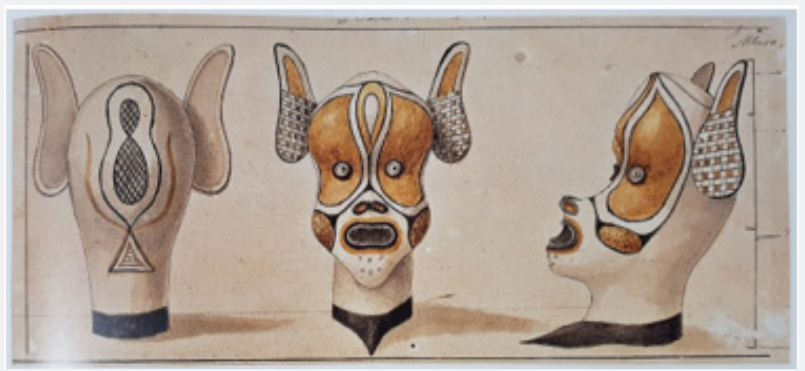

Watercolor; 9.4 × $21 \mathrm{~cm}$; W. 1817-1829. Museums Castro Maya, Rio de Janeiro

Figure 2: Indian mask, monkey head. J. B. Debret [20].

The watercolor has the fastest drying and allows, through thin transparent and superposed layers, to capture with agility a detail among other minutiae found by Debret. It is valid to emphasize that an image is not the reflection of the real but what is perceived and passed to the paper from the perspective of the artist, which is inserted in a certain universe. The art historian Jorge Coli calls attention to the importance of gaze as one of the most fruitful attitudes for the study of our artistic heritage of the nineteenth century. The look is primordial for the art of any period and any country, in particular for the nineteenth century, emphasizes the historian. That said, we can say that the relation of the spectator to the image encompasses a series of "events": temporality, imagination, memory, history, perception, dialogue, affection, culture. Like a reader, the spectator, when observing an image, initiates a dialogue with the object and the awakening of the senses. In this way, in order to cross our gaze in the face of the works, we raise questions that point to instigating aspects for the reflection of the historian who intends to work with iconographic sources, that is, the world in which it inserts and translates, and the perspective that the same builds and reveals. 


\section{Global Journal of Archaeology \& Anthropology}

\section{Final Considerations}

The process of knowledge of the ritualistic masks of the Tikuna peoples began, we became aware of the importance of the mythology of the indigenous peoples, not in their figurative sense, but as these groups experienced it as a sacred experience, constituted by all the knowledge transmitted from generation to generation generation. According to the anthropologist and philosopher Claude Lévi-Strauss [22], it is through masks that the music and mythology of a given culture reach a symbolic approach. In relation to watercolor, located in the [23] of the Museum of the Chácara do Céu (Castro Maya Museums) in Rio de Janeiro, undoubtedly the legacy left by Debret opens many possibilities for us to read on the part of the History of Art and Cultural History, fields that have been firmly established in Brazilian historiography contemporary art. About the image, its concept as representation encompasses a series of assumptions between time, the object of observation and the observer. Reading an image always presupposes starting from restlessness, values, inquiries; which thus create possibilities for interpreting and reading the images. We must emphasize the importance of this work as an essential part of our history and our identity: a rich material referring to nineteenth-century Brazil that offers a new impetus for current and future research.

Faced with the catastrophe in the National Museum [24] , a tragedy not only for the Amazon and for Brazil, but for the world, it is even more important to reinforce the discourse of struggle and safeguarding before our collective memories. The fire of the museum reflects the neglect with the national patrimony, science and technology; besides revealing to us the lack of policies of preservation of the artistic, material and documentary patrimony in Brazil. It is necessary to safeguard the Tikuna culture and the caution of the debretian works, along with our history and memory. It is urgent that we need to denounce these issues both through history and through public archeology, for "a people without memory is a people without history. And a people without history is bound to commit, in the present and in the future, the same mistakes of the past [25-42]".

\section{References}

1. In spite of being a recent field, resulting from transformations in societies and archeology, the term "Public Archeology" was mentioned for the first time in the United States in 1972 in the work of Charles Mc Gimsey III, added to the practical issues related to the management of cultural heritage, differing from academic studies. In Brazil, public archeology began to be reflected in the 1980s, with political democratization. From this process of reflection on methods, practices, values and meanings, Brazilian archeology was born.

2. Jacques-Louis David, Le Serment des Horaces, (The Oath of the Horácios), 1784-5, oil on canvas, 330 x 425 cm. Musée du Louvre, Paris.

3. Exhibition catalog: Debret and the French artistic mission in Brazil: 200 years - curated by Jacques Leenhardt. Rio de Janeiro, Brazil: Castro Maya Museums, Artepadilla, 2016, p. 9.

4. The term "Artistic French Mission" is used in quotation marks, because at the time there was no idea formed of "Mission". SCHWARCZ, Lilia Moritz. The Sun of Brazil. Nicolas-Antoine Taunay and the misadventures of the French artists in the court of D. João. São Paulo: Companhia das Letras, 2008, p.179

5. In addition to Jean-Baptiste Debret, we can cite here the NicolasAntoine Taunay (1755-1830), landscape painter; Auguste Henry Victor Grandjean de Montigny (1776-1850), architect; Auguste Marie Taunay (1768-1824), sculptor; Charles Simon Pradier (1786-1848), engraver In 1817, the brothers Marc and Zépherin Ferrez joined the group, the first as a sculptor and the second as a sculptor and medal engraver.

6. The work of Bandeira e Lago, the result of ten years of research, systematized the artist's production in a total of 1000 works (including sketches, oils and watercolors). Bandeira, Júlio; LAGO, Pedro Corrêa. Debret and Brazil: complete work, 1816-1831. Rio de Editora Capivara, Janeiro, Brazil.

7. The IHGB Review, which received the first volume dedicated to the Indians and aspects of the Brazilian forest and native vegetation in general (which were dominant patterns in the book market in Europe at that time), criticizes the second and third volumes ( which focus on the representation of slaves, small urban work and agricultural workers and practices of the time), declaring that the work is of little interest to Brazil.

8. Bandeira Lago (2009) The main source of inspiration for Indian sketches is the engravings of Spix and Martius's album published in 1823 and which must have been one of the earliest illustrated books to arrive at the hands of Debret, pp. 372.

9. Dr. Johann Baptist von Spix (1781-1826), Doctor of Medicine, and Carl Friedrich Philipp von Martius (1794-1868), physician, botanist and naturalist, landed in Rio de Janeiro in 1817, integrating the group of scholars who accompanied by D. Leopoldina. The Germans embarked on a three-year voyage that surrounded Brazil, traversing its interior and coast, in order to study the various faces of the new nation.

10. The German prince Maximilian of Wied-Neuwied (1782-1867), traveled from Rio de Janeiro to Bahia, making records mainly in the field of zoology, but also on life in society, including contacting several indigenous tribes whose vocabularies collected.

11. Lithography was invented in Germany in the late eighteenth century by Alois Senefelder, this printing technique uses the stone as a matrix and is based on the principle of repulsion between fat and water. The drawing is done on a limestone composition stone with lithographic ink or pencil, both greasy. A solution of acidulated gum arabic is then used to cover the entire surface. The parts protected by the fat are smooth, while the exposed parts are attacked by the acid and acquire a porous texture. The matrix is cleaned and fed to the lithographic press where it is moistened and with the aid of a roll a greasy paint is applied. The porous areas, which absorbed the water, repel the ink, which is retained only on the smooth areas of the stone, which define the image to be printed. Instituto Moreira Salles - Glossary of Graphic and Photographic Techniques and Processes of the $19^{\text {th }}$ Century.

12. To see: http://pib.socioambiental.org/pt/povo/Tikuna/1343. Last access on April 14, 2019.

13. Gruber (1999) According to the Tikuna myth, Tetchi arü Ngu'i, Yo'i's wife betrayed him with his brother Ipi. He is considered the mischievous hero who violates the prohibitions and practices incorrect actions. And from this betrayal, according to the myth, the act of childbirth suffers for women. As the myth reveals to the people the origin of things, with the birth of the son and to take revenge on the brother, Yo'i ordered Ipi to obtain the fruit of the genipapo for mother to paint the newborn child. This practice is based on the myth that, until today, is cultivated by the natives in the ceremonies of feminine initiation and appointment of the children. Ipi had a hard time picking up the fruit from the tree that, according to mythology, kept growing closer to the sky. After a great effort, Ipi managed to reach the fruit and descended rolling from the tree, turning into a tucandeira with the fruit in the mouth. Then Yo'i ordered Ipi to grate the fruit without stopping. He obeyed and grated the fruit, without stopping, until he grated his 
whole body. Thus, Tetchi arü Ngu'i took the juice from the genipap and painted the child and then threw the sludge in Igarapé Évare, which is the sacred land of the Tikuna. The rubble of the genipapo descended water down and went to a place where there was much gold. Then the rubble emerged again and turned into small fish, a large pyramidal. When the piracema passed, Y'oi made a reed and went to fish using a mature tucumã lump. But the fish, when they fell on the land, turned animals: peccary, tapir, deer, caititu, and many others. Then Y'oi used bait of macaxeira, and, with that bait, the fished fish became people. Y'oi took advantage of and fished many people, who generated the Tikuna people, p. 18.

14. It is a rite of female passage and consists of the transition of the girl from one social status to another in the Tikuna community after her menarche.

15. Gruber (1992) Jussara Gomes. The graphic art Tikuna. In: VIDAL, Lux (Org.). Indigenous graphics: studies of aesthetic anthropology. São Paulo: Studio Nobel: Publisher of the University of São Paulo, Brazil, pp. 249.

16. Gruber (1994) Jussara Gomes. Museu Magüta. Piracema, Brasília, Brasil: Funarte/Ibac/Minc 2(2): 84-94.

17. Current National Museum of the Federal University of Rio de Janeiro.

18. As part of my master's research, I visited the National Museum in 2013, where I was able to see artifacts from the Tikuna indigenous culture (including animal masks). Monkey Mask - Photography: Mariane Pimentel Tutui, Brazil.

19. Bandeira (2009) Júlio; LAGO, Pedro Corrêa. Debret eo Brasil: obra completa, 1816-1831. Rio de Janeiro, Brasil: Editora Capivara, pp. 377.

20. Archaeological, anthropological, geological and paleontological artifacts were destroyed, as well as hundreds of thousands of books and documents, audios and recordings of extinct indigenous languages. In addition to the indigenous artifacts, there were documents from the Empire era, fossils, mineral collections, Greco-Roman artifacts and the largest Egyptian collection in Latin America. Among its best-known items were the skeleton of the largest Brazilian carnivorous dinosaur and the oldest human fossil discovered in Brazil.

21. The destruction of this collection collected by Gonçalves Dias, a scholar and scientist in the study of indigenous languages, which has never been studied and was not exposed, has incalculable proportions.

22. Lévis-Strauss (1978) Claude. Mito e Significado. Lisboa, Edições, Portugal, 70: 28.

23. Debret is highlighted in this collection with a series of watercolors, drawings, gouaches and engravings that are part of the collection of Brasiliana of the Castro Maya Museums. To know more, see: TUTUI, Mariane Pimentel. The experience of the research in the Museum of the Chácara do Céu- Castro Maya Museums.

24. The exhibition Nacional Museu Vive - Arqueologia do Resgate (National Museum of Lives), which presents more than 100 works rescued from the fire that destroyed the main building of the National Museum, is open. The exhibition that celebrates the restart of the museum is on display at the Centro Cultural Banco do Brasil (CCBB), in Rio de Janeiro from $02 / 27 / 2019$ to $04 / 29 / 2019$.

25. The quote is from Emília Viotti da Costa, a Brazilian historian and teacher.

26. Araujo (2019) Ana Lucia. The Death of Brazil's National Museum. The American Historical Review 124: 569-580.

27. Bandeira (2009) Júlio; Lago, Pedro Corrêa. Debret e o Brasil: obra completa, 1816-1831. Rio de Janeiro, Editora Capivara, Brasil.

28. Catálogo de exposição: Debret e a missão artística francesa no Brasil: 200 anos - curadoria de Jacques Leenhardt. Rio de Janeiro, Brasil: Museus Castro Maya, Artepadilla, 2016, p.9.

29. Coli (2006) Jorge. Como estudar an arte brasileira do século XIX? São Paulo, Brasil: Editora Senac p.18.

30. Debret (2016) Jean-Baptiste, 1768-1848. Viagem Pitoresca e Histórica ao Brasil. Tradução e notas de Sérgio Milliet / Organização e prefácio Jacques Leenhardt. São Paulo, Editora Imprensa Oficial do Estado de São Paulo, Brasil.

31. Viagem Pitoresca e Histórica ao Brasil. Tradução e notas de Sérgio Milliet / apresentação de M. G. Ferri - Belo Horizonte: Ed. Itatiaia Limitada; São Paulo, Universidade de São Paulo, 1978. Tomo I, Brasil.

32. Viagem pitoresca e histórica ao Brasil. - tradução e notas de Sérgio Milliet, notícia biográfica de Rubens Borba de Moraes. São Paulo Martins (Eds.), da Universidade de São Paulo, Brasil, 1972.

33. Caderno de Viagem (2006) (Texto e Organização: Júlio Bandeira), Rio de Janeiro, Editora Sextante Artes, Brasil.

34. Funari, Pedro Paulo A, Robrahn-González E (2008) Ética, capitalismo e arqueologia pública no Brasil. História. São Paulo, Brasil, 27(2): 13-30.

35. Gruber Jussara Gomes (1992) A arte gráfica Tikuna. In: Vidal, Lux (Org.). Grafismo indígena: estudos de antropologia estética. São Paulo: Studio Nobel: Editora da Universidade de São Paulo, Brasil.

36. Museu Magüta (1994) Piracema, Brasília, Brasil: Funarte/Ibac/Minc 2(2): 84-94.

37. O Livro das Árvores (1999) 3a. ed. São Paulo, Global, Brasil.

38. Lévis-Strauss Claude (1978) Mito e Significado. Lisboa, Edições, Portugal, p. 70.

39. Lima Valéria JB (2008) Debret. Historiador e Pintor. Campinas, Editora da Unicamp, Brasil.

40. Schwarcz, Lilia Moritz O (2008) Sol do Brasil. Nicolas-Antoine Taunay e as desventuras dos artistas franceses na corte de D. João. São Paulo, Companhia das Letras, Brasil.

41. Tutui Mariane Pimentel (2014) As Representações da Festa em Debret: Um destaque ao Dia d'Entrudo e à Marimba. Dissertação (Mestrado em História). Universidade Estadual de Maringá.

42. Aquarelas do Brasil: A importância dos registros pictóricos de Debret. Artigos do Patrimônio - IPHAN, 2015. Disponível em, Brazil. 
- Quality Editorial service

- Swift Peer Review

- Reprints availability

- E-prints Service

- Manuscript Podcast for convenient understanding

- Global attainment for your research

- Manuscript accessibility in different formats

( Pdf, E-pub, Full Text, Audio)

- Unceasing customer service

Track the below URL for one-step submission https://juniperpublishers.com/online-submission.php 